\title{
TWO PROBLEMS IN ADMINISTRATIVE LAW: POLITICAL POLAFITY ON THE DISTRICT OF COLUMBIA CIRCUIT AND JUDICIAL DETERRENCE OF AGENCY RULEMAKING
}

\author{
RICHARD J. PIERCE, JR.*
}

In a refreshingly candid article, Chief Judge Wald of the D.C. Circuit noted in 1986: "The flow of membership in the D.C. Circuit . . is inore like what one would expect in Congress with elections every few years, or in the Executive, shifting its key policymakers with each administration." Eleven of the twelve D.C. Circuit judges were appointed by President Reagan or President Carter within the last nine years. Most served previously in policymaking positions in either the legislative or executive branches of government. Based on their record of decisionmaking with respect to judicial review of agency actions, the new members of the D.C. Circuit seem to be experiencing a difficult, and as yet incomplete, transition from their prior active role in the partisan pohtical process.

Two probleins have emerged in the D.C. Circuit's review of agency decisions. First, the democratic and republican judges on the D.C. Circuit see agency policy decisions through dramatically different prisms. Deeply ingrained differences in pohtical perspective become particularly apparent when the D.C. Circuit reviews agency policy decisions with signiffcant ideological implications: the fate of a major agency policy decision reviewed by the D.C. Circuit will vary with the composition of the panel that reviews the agency action. ${ }^{2}$

Second, policymaking through agency rulemaking has dechined significantly at some agencies during the past decade. ${ }^{3}$ While other factors

* Visiting Professor, Columbia University School of Law; George W. Hutchison Professor of Law, Southern Methodist University. B.S. 1965, Lehigh University; J.D. 1972, University of Virginia. I am grateful for the helpful comments and criticisms of Peter Strauss.

1. Wald, Rebel Angel in Flight, District Law., July/August 1986, at 30, 32.

2. "In our court right now, the result in close or controversial cases can turn on the composition of the panel." Id. at 32.

3. T. MCGARITY \& S. SHAPIRo, REPORT TO THE ADMINISTRATIVE CONFERENCE ON OSHA Rulemaking (1987); S. Melnick, Regulation and the CourTs (1983); Mashaw \& Harfst, 
have contributed to this trend, 4 the approach taken by appellate courts when they review agency rules dominates the hist of explanatory factors. ${ }^{5}$ The present D.C. Circuit is less deferential to the political branches of government than its predecessors. It affirms agency actions far less frequently than did its predecessors. In reversing agency pohicies adopted through the rulemaking process, the D.C. Circuit frequently substitutes its own interpretations for agency interpretations of ambiguous statutory provisions $^{6}$ and imposes rigorous requirements that agencies support each element of a pohicy decision with detailed discussion of factual predicates and comprehensive reasoning from factual premises to policy conclusions. ${ }^{7}$ In contrast, courts are less demanding when they review agency policyınaking undertaken through ad hoc adjudication of specific cases. ${ }^{8}$ As a result, some agencies are abandoning systematic approaches to pohcymaking in favor of ad hoc pohicymaking.

These two phenoinena are closely related in their functional effects on agencies. When an agency begins the process of policymaking through rulemaking, or considers mitiation of that process in an important context, it knows that it must be prepared to satisfy the rigorous requirements of some court of appeals at the end of the process. If the agency does not discuss in detail each of the hundreds of issues raised by participants in the rulemaking and each of the many studies submitted in the proceeding, it risks judicial reversal and remand of its policy. Thus, to avoid a holding that its pohicy is arbitrary and capricious, the agency must prepare a "concise general" statement of basis of purpose that consists of hundreds of pages of detailed discussion of every conceivable issue raised by its policy mitiative. ${ }^{9}$ In this judicial environınent, an

Regulation and Legal Culture: The Case of Motor Vehicle Safety, 4 YALE J. REG. 257, 263-68 (1987); Schwartz, The Consumer Product Safety Commission: A Flawed Product of the Consumer Decade, 51 Geo. WASH. L. REv, 35 (1982).

4. The Reagan Adininistration's minimalist attitude toward governinent intervention probably has contributed to the reduced level of rulemaking. Congressional requirements that some agencies permit cross-examination in rulemaking proceedings undoubtedly has contributed to the trend in those agencies. E.g., 15 U.S.C. $\$ 2058$ (d)(2) (1982); 29 C.F.R. $\$ 1911.15(3)$ (1987); see McGarity, OSHA's Generic Carcinogen Policy: Rulemaking Under Scientific and Legal Uncertainty, in LAW AND SCIENCE IN Collaboration (J. Nyhard \& M. Carrow eds. 1983); Schwartz, supra note 3.

5. Mashaw \& Harfst, supra note 3, at 276-99.

6. E.g., Union of Concerned Scientists v. NRC, 824 F.2d 108 (D.C. Cir. 1987); Jersey Central Power \& Light v. FERC, 810 F.2d 1168 (D.C. Cir. 1987); Middle South Energy, Inc. v. FERC, 747 F.2d 763 (D.C. Cir. 1984), cert. dismissed, 473 U.S. 930 (1985).

7. E.g., Electricity Consuners Resource Council v. FERC, 747 F.2d 1511 (D.C. Cir. 1984); International Ladies Garment Workers' Union v. Donovan, 722 F.2d 795 (D.C. Cir. 1983), cert. denied, 469 U.S. 820 (1984); Chrysler Corp. v. Department of Transp., 472 F.2d 659 (6th Cir. 1972).

8. See Mashaw \& Harfst, supra note 3, at 299-302.

9. The Adıninistrative Procedure Act requires only that an agency accompany rules with "a concise general statement of their basis and purpose." 5 U.S.C. $\$ 553(\mathrm{e})$ (1982). Courts have re- 
agency realistically must conclude that making an important poticy decision through the rulemaking process will require it to commit a significant proportion of its scarce resources to that process for as much as a decade. ${ }^{10}$

An agency must also be aware that a reviewing court may not allow it to implement its policy even after a lengthy and costly rulemaking process. In some circumstances, the agency knows from the outset that its rule will be reviewed by the D.C. Circuit. ${ }^{11}$ In most circumstances the agency at least knows that there is a high probability of D.C. Circuit review. ${ }^{12}$ The D.C. Circuit reverses or remands over sixty percent of all agency actions it reviews. ${ }^{13}$ The agency cannot know the composition of the D.C. Circuit panel that will review the product of its rulemaking, but it can predict that the likehhood of reversal will depend im part on whether the panel includes a majority of democrats or a majority of republicans. In cases with significant ideological imphications-most major agency rulemakings-democratic D.C. Circuit judges are more likely to reverse agency pohcies at the behest of individuals, and republican D.C. Circuit judges are more likely to reverse agency pohicies challenged by business imterests. Thus, the agency must conclude that the risk of reversal of a major policy decision is high and depends in part on a variable that can neither be predicted nor controlled by the agency whose policy decision is subject to review-the composition of the panel that reviews the policy.

The combined effect of the demanding attitude of circuit courts generally toward agency policymaking through rulemaking, and the increasing political polarity of the members of the D.C. Circuit on any issue with significant ideological implications, is threefold. First, the time required to make policy through rulemaking has been stretched to nearly a decade. Second, the cost to the agency of making pohicy through rulemaking has increased significantly. Fmally, assessing the likelihood of success in making policy through rulemaking mcreasimgly resembles the process of predicting the results of a lottery. If these two problems persist, more agencies will react either by declining to make pohicy deci-

fused, however, to give meaning to the adjectives "concise" and "general." See Automotive Parts \& Accessories Ass'n v. Boyd, 407 F.2d 330, 338 (D.C. Cir. 1968).

10. See Mashaw \& Harfst, supra note 3, at 284-89.

11. A few statutes confer exclusive jurisdiction on the D.C. Circuit. E.g., 42 U.S.C. $\S 7607(\mathrm{~b})(1)(1982)$.

12. Over one quarter of all agency actions were appealed to the D.C. Circuit in 1986. ANNUAL REPORT OF THE DIRECTOR OF THE ADMINISTRATIVE OFFICE OF THE UNITED STATES COURTS 101 (1986).

13. ANNUAL Report of THE Director of the ADMINISTRATIVe OfFICE OF THE UNITED STATES COURTS 155 (1987) [hereinafter 1987 ANNUAL REPORT]. 
sions at all, or by disguising policy decisions as resolutions of specific, narrow disputes.

In part I, I describe the dimensions of the two related probleins. ${ }^{14}$ In part II, I propose solutions to the problems. ${ }^{15}$ The solutions to the. two problems are the same, and each is supported by recent decisions of the Supreme Court and of the D.C. Circuit. Those decisions liold that, in a variety of contexts, judges should defer to policy decisions made by politically accountable agencies. Thus, at the inost basic level, judges can solve the problems of political polarity on the D.C. Circuit and judicial deterrence of agency ruleinaking simply by applying precedents in a consistent manner.

\section{The Dimensions of the Problem}

\section{A. Ideology in the D.C. Circuit.}

The ideology of meinbers of the D.C. Circuit lias long been a major factor in the court's review of agency actions. Professor (now Justice) Scalia engaged im a bitmg attack on the D.C. Circuit in 1978. He mdicted the D.C. Circuit for substituting its own view of proper policy for the views of the politically accountable branches of government, thereby ignoring Supreme Court precedent to the contrary. He cited numerous examples of cases in which the D.C. Circuit continued to base its administrative law decisions on its own ideology notwithstanding consistent pointed rebukes from the Supreme Court. ${ }^{16}$

The New York University Law Review's careful study of the D.C. Circuit's record in the Supreme Court during the period 1980-1983 documented a continuation-imdeed an increase -im the D.C. Circuit's tendency to play a major role in the nation's pohicymaking process, and of that circuit's probleins in the Supreme Court. ${ }^{17}$ During that four year period, the Supreine Court granted petitions for certiorari from the D.C. Circuit nearly three times as often as from otlier circuits. ${ }^{18}$ The Court affirmed the D.C. Circuit only 10.4 percent of the time-one-fourth the affirmance rate of other circuits. ${ }^{19}$

14. See infra notes $16-83$ and accompanying text.

15. See infra notes 84-156 and accompanying text.

16. Scalia, Vermont Yankee: The APA, the D.C. Circuit, and the Supreme Court, 1978 SuP. CT. REV. 345; see also Verkuil, Waiting for Vermont Yankee II, 55 TUL. L. REV. 418 (1981).

17. Note, Disagreement in D.C.: The Relationship Between the Supreme Court and the D.C. Circuit and Its Implications for a National Court of Appeals, 59 N.Y.U. L. REV. 1048 (1984). But see Edwards, Public Misperceptions Concerning the "Politics" of Judging: Dispelling Some Myths About the D.C. Circuit, 56 U. Colo. L. REv. 619 (1985).

18. Note, supra note 17, at 1063.

19. Id. at 1050 . 
NYU evaluated several possible explanations for the D.C. Circuit's record in the Supreme Court and rejected all but one-the Supreme Court and the D.C. Circuit are ideologically imcompatible. ${ }^{20}$ The NYU study found that the D.C. Circuit and the Supreme Court were in disagreement over three fundainental issues: (1) the D.C. Circuit sees net social benefits in judicial supervision of government activity in a wider range of circumstances than does the Supreine Court; (2) the Supreme Court is more willing to defer to the politically accountable branches of government than is the D.C. Circuit; and (3) the D.C. Circuit is inore protective of the rights of individuals against the government than is the Supreme Court. ${ }^{21}$ In short, the D.C. Circuit consistently expanded the role of the judiciary in policymaking, while the Supreme Court attempted to force the D.C. Circuit to assume a less expansive role in government policymaking. The Supreme Court's efforts to date have not been successful. Indeed, in a 1988 article Chief Judge Wald characterized the D.C Circuit's role as that of an "aggressive semior partner" in the administrative process. ${ }^{22}$

From 1983 through 1986, the political coinposition of the D.C. Circuit changed significantly as a result of President Reagan's appoimtment of seven republican judges. ${ }^{23}$ This change had the potential to decrease the ideological differences between the Supreme Court and the D.C. Circuit by reducing the tendency of the D.C. Circuit to assume a dominant role in government policyinaking. After all, President Reagan and former Attorney General Meese regularly extol the virtues of judicial restraint and deference to the politically accountable branches of governinent. Presumably, the Reagan administration's appointees would share this philosophy. Moreover, there was evidence that the historic tendency toward judicial activism on the D.C. Circuit and the ideological incompatibility of the D.C. Circuit and the Supreme Court were rooted in the democratic members of the Circuit. Indeed, during the period 1980-1983, the Supreme Court reversed the D.C. Circuit in every case in which it granted review of a D.C. Circuit opinion written by one of the four judges appointed by President Carter. ${ }^{24}$

This potential has not been realized. The D.C. Circuit has beconie more conservative politically, but it has not becoine more deferential to the politically accountable branches of government. The D.C. Circuit's

20. Id. at $1050,1060-63$.

21. Id. at 1051-59.

22. Wald, The Contribution of the D.C. Circuit to Administrative Law, 40 ADMIN. L. REV. (forthcoming, fall 1988).

23. One of the seven, Justice Scalia, subsequently was elevated to the Supreme Court.

24. Note, supra note 17 , at 1066 n.95. 
rate of affirmance of agency actions has shrunk dramatically to less than thirty percent, compared with an agency affirmance rate of seventy-four percent for all other circuits ${ }^{25}$-scarcely a sign of increased deference to the pohtically accountable institutions of government. I cannot identify all of the many factors that undoubtedly have contributed to this phenomenon, but one is apparent. The new republican members of the court are more sympathetic than their democratic colleagues when representatives of business interests claim that an agency has unlawfully harmed a business interest. Two decisions reversing actions taken by the Federal Energy Regulatory Commission (FERC) illustrate the combimation of political conservatism and judicial activism that is sometimes shown by the republican judges on the D.C. Circuit.

In Middle South Energy v. Federal Energy Regulatory Commission, ${ }^{26}$ the agency had interpreted the Federal Power Act (FPA) to empower it to suspend, pending investigation, an initial rate filing. The agency based its interpretation on a 1978 Supreme Court decision affirmmg an identical interpretation of the Interstate Commerce Act (ICA), ${ }^{27}$ after which the FPA was modeled. ${ }^{28}$ The republican majority of the D.C. Circuit panel reversed the agency, distimguishing on subtle grounds the arguably controlling Supreme Court opinion. ${ }^{29}$ The dissenting judge (a democrat) chided the majority for failing even to discuss the deference due an agency's interpretation of the provisions of its orgamic act under the Supreme Court's 1984 decision in Chevron U.S.A. Inc. v. Natural Resources Defense Council, Inc. ${ }^{30}$

In Jersey Central Power \& Light Co. v. Federal Energy Regulatory Commission, ${ }^{31}$ the agency had allowed an electric utility to recover in its rates all of its investment in a cancelled generating plant but had disallowed any return on that investment. The agency's action was based on a unanimous 1938 Supreme Court decision, Denver Union Stock Yard Co. v. United States. ${ }^{32}$ Denver Union announced a doctrme that the D.C. Circuit had in turn characterized as "a bedrock principle of utility rate regulation" only two years before its decision in Jersey Central. ${ }^{33}$ In-

\footnotetext{
25. 1987 ANNUAL REPORT, supra note 13 , at 155 .

26. 747 F.2d 763 (D.C. Cir. 1984).

27. Trans Alaska Pipeline Rate Cases, 436 U.S. 631 (1978).

28. 747 F.2d at 767.

29. Id. at $768-69$.

30. 467 U.S. 837 (1984); Middle South Energy, 747 F.2d at 774 (R. Ginsburg, J., dissenting).

31. 810 F.2d 1168 (D.C. Cir. 1987).

32. 304 U.S. 470 (1938).

33. Kentucky Utils. Co. v. FERC, 760 F.2d 1321, 1324 n.4 (D.C. Cir. 1985). See generally Hoocker, "Used and Useful": Autopsy of a Ratemaking Policy, 8 ENERGY L.J. 303 (1987) (discussing evolution and applications of the "used and useful" concept).
} 
deed, FERC's policy on cancelled plants was far more generous to electric utilities than the policies of the majority of states, ${ }^{34}$ and the D.C. Circuit had affirmed a less generous policy adopted by FERC in the context of gas utilities only two years prior to the Jersey Central decision. ${ }^{35}$ Yet, four republican members of the court (jomed by one democrat) reversed the agency policy at issue in Jersey Central. Over a vigorous dissent by four democrats who urged deference to the politically accountable branches of governinent, ${ }^{36}$ the republican majority held that a utility has a right to earn a return on an investment even if the investment never provides benefits to consumers if the utility can show that it otherwise will experience financial difficulties.

The D.C. Circuit is divided between political liberals and potitical conservatives, but the court's basic ideology remains one of judicial activism. Indeed, Judge Wald has noted that, notwithstanding their sharp differences of opinion on inany issues, the judges of the D.C. Circuit agree on the importance of "hard look" review of the agency pohicymaking process. ${ }^{37}$ Thus, the ideological incompatibility of the D.C. Circuit and the Supreme Court, documented by Justice Scalia in 1978 and by NYU in 1985, persists in 1988. Moreover, agencies lave inore reason than ever to fear reversal of their policy decisions by the D.C. Circuit. The court affirms agencies far less frequently than in the past, and it reverses or remands agency actions at the behest of a wider range of parties than was its practice when the court was dominated by democrats.

The lottery characteristic of the D.C. Circuit will be difficult to eliminate. Most ineinbers of the court seem to liave little regard for stare decisis, and en banc proceedings do not provide a promising vehicle for reconciling the stark differences in poitical perspective that now pervade the court's decisionmaking. ${ }^{38}$ The court can accommodate only about six en banc proceedings per year. ${ }^{39}$ Moreover, the government often declines to seek rehearing en banc when a panel reverses an agency policy that displeased a significant constituency of the administration. ${ }^{40}$

34. See Pierce, The Regulatory Treatment of Mistakes in Retrospect: Cancelled Plants and Excess Capacity, 132 U. PA. L. REv. 497, 517-20 (1984) (citing examples of state regulatory commissions denying return on investment for cancelled plants).

35. Natural Gas Pipeline Co. of Am. v. FERC, 765 F.2d 1155, 1163-64 (D.C. Cir. 1985), cert. denied, 474 U.S. 1056 (1986).

36. 810 F.2d at 1202 (Mikva, J., dissenting).

37. Wald, supra note 22 .

38. "In a court with strong ideological differences, some panels display outwardly their animus to past precedent in the circuit ...." Wald, supra note 1, at 34 .

39. Id. at 33 .

40. Id. at 32 . 
The D.C. Circuit's 1987 en banc decision in Bartlett v. Bowen illustrates both the degree of political polarity on the court and the difficulty of atteinpting to obtain intracircuit consistency through en banc proceedings. ${ }^{41}$ Bartlett involved three unrelated cases previously decided by panels that included a najority of deinocrats. The facts and issues of the three cases are not important for present purposes. In Bartlett, a sixjudge majority consisting of five democrats and one republican reversed sua sponte orders previously granting reliearing en banc in the three cases. Five republican judges wrote a scathing joint statement of dissent. The deinocrats characterized the panel decisions written by democrats as "routme" and "run-of-the mill," 42 while tlie dissenting republicans characterized the issues as of "exceptional importance" and the decisions of the democratic panels as "clearly wrong." 43 Each group accused the other of atteinpting to engage in "sweeping and revolutionary" changes in the law. ${ }^{44}$

After reading the opinions of the court en banc in Bartlett, and a representative sainple of panel opinions in other cases with significant political implications, an agency administrator is likely to conclude that the fate of any major policy the agency attempts to inipleinent is largely dependent on the composition of the D.C. Circuit panel assigned to review the pohcy. That realization alone will inake agencies reluctant to make pohicy decisions. Alternatively, it inight lead thein to disguise their policy decisions as ad hoc adjudications of specific disputes.

41. 824 F.2d 1240 (D.C. Cir. 1987); see also Center for Auto Safety v. Thomas, 847 F.2d 843, 844, 863 (D.C. Cir. 1988) (en banc) (5 democratic judges would hold that public interest groups have standing; 5 republican judges would hold the opposite); Hammon v. Barry, 841 F.2d 426, 427 (D.C. Cir. 1988) (en banc) (7 republican judges vote to vacate order granting rehearing en banc; 5 democratic judges dissent, saying "it is hard to recall an instance where leading precedents of the Supreme Court have been given shorter shrift by this court"); Wolfe v. Department of Health \& Human Servs., 839 F.2d 768, 769, 776, 779 (D.C. Cir. 1988) (en banc) (7 republican judges vote to reverse panel decision; 5 democratic judges dissent); Durns v. Bureau of Prisons, 806 F.2d 1122 (D.C. Cir. 1986) (en banc) (6 republican judges vote against rehearing en banc; 5 democratic judges dissent); Telecommumications Research \& Action Center v. FCC, 806 F.2d 1115 (D.C. Cir. 1986) (en banc) (four republican judges vote against rehearing en banc; four democratic judges and one republican judge dissent). Political polarity is also evident in the decisions of panels. I identified 34 cases reported in volumes 804 through 831 of the Federal Reporter, Second Series in which members of panels differed concerning the validity of agency actions. In 26 of those cases, $76 \%$, the differences were between democrats and republicans. In only five cases, two republicans disagreed. In only three cases, two democrats disagreed. A computer analysis of all non-unamimous panel decisions during 1987 demonstrates even more starkly the extreme degree of political polarity on the D.C. Circuit. Of the eleven judges who participated in decisionmaking during that period, a group of eight, consisting of four republicans and four democrats, divided on purely partisan lines in virtually all cases. Karpay, Bork or No Bork, GOP Bloc a Force on D.C. Circuit, Legal Times, Jan. 18, 1988, at $10-12$.

42. 824 F.2d at 1242 .

43. Id. at 1247 (Bork, Starr, Buckley, Willians \& D.H. Ginsburg, JJ., dissenting).

44. Id. at 1243,1248 . 


\section{B. Judicial Deterrence of Agency Rulemaking.}

Judges and academics long ago reached rare consensus on the desirability of agency policymaking through the process of informal rulemaking. ${ }^{45}$ Justices Harlan and Douglas attempted to convince a majority of their colleagues to compel agencies to make policy decisions exclusively through the rulemaking process. 46 The Supreme Court wisely abandoned that effort in recognition that it is impossible for agencies to make all policy decisions generically in advance, and that agencies are best positioned to determme the circumstances im which the many advantages of rulemaking must be sacrificed for the flexibility of ad hoc policymaking through adjudication. ${ }^{47}$

Still, courts consistently recognize the advantages of rulemaking and frequently strive to encourage agencies to make policy primarily through the rulemaking process. Many of the landmark decisions in administrative law are explicable in part by reference to the nearly unanimous judicial preference for pohicymaking through rulemaking. ${ }^{48}$ Judges and scholars have identified eight significant advantages inherent in the rulemaking process as a ineals of making policy decisions. ${ }^{49}$

Rulemaking yields ligher-quality policy decisions than adjudication because it invites broad participation in the pohcymaking process by all affected entities and groups, and because it encourages the agency to focus on the broad effects of its policy rather than the often idiosyncratic adjudicative facts of a specific dispute. Rulemaking enhances efficiency in three ways. It avoids the needless cost and delay of finding legislative facts through trial-type procedures; it eliminates the need to relitigate policy issues in the context of disputes with no material differences in adjudicative facts; and, it yields much clearer "rules" than can be extracted from a decision resolving a specific dispute. Rulemaking also provides greater fairness in three ways. It provides affected parties with clearer notice of what conduct is permissible and impermissible; it avoids the widely disparate temporal impact of agency policy decisions made

45. See generally $1 \mathrm{~K}$. Davis, Administrative Law Treatise $\$ 6.38$ (2d ed. 1978); J. Mashaiw \& P. Merrill, administrative Law: The american Public law System 273316, 385-413 (2d ed. 1985); R. Pierce, S. Shapiro \& P. Verkuil, Administrative LaW aND Process § 6.4.1 (1985); Bernstein, The NLRB's Adjudication-Rule Making Dilemma Under the Administrative Procedure Act, 79 YALE L.J. 571 (1970); Shapiro, The Choice of Rulemaking and Adjudication in the Development of Administrative Policy, 78 HARv. L. REv. 921 (1965).

46. See, e.g., NLRB v. Wyman-Gordon Co., 394 U.S. 759, $777-78$ (1969) (Douglas, J., dissenting); id. at 781-82 (Harlan, J., dissenting); California v. Lo-Vaca Gathering Co., 379 U.S. 366, 37677 (1965) (Harlan, J., dissenting).

47. See NLRB v. Bell Aerospace Co., 416 U.S. 267, $290-95$ (1974); see also SEC v. Chenery Corp., 332 U.S. 194, 199-204 (1947).

48. See R. Pierce, S. ShapiRo \& P. VerkuiL, supra note 45, §§ 6.4.1a, 6.4.1c, 6.4.7.

49. See supra note 45 and sources cited therein. 
and implemented through ad hoc adjudication; and, it allows all potentially affected segments of the public to participate im the process of determining the rules that will govern their conduct and affect their hives.

Notwithstandimg the near-universal recogmition that rulemaking is a superior vehicle for agency policymaking, the courts inadvertently have created several powerful deterrents to the use of that vehicle over the last twenty years. This problem is not unique to the D.C. Circuit; all circuits, and even the Supreme Court, have contributed to the problem im some measure..$^{50}$ Some agencies do not even attempt to make pohicy through rulemaking any more. ${ }^{51}$ When they do, the process of promulgating a rule that is likely to be affirmed by a reviewing court now approaches a decade in many cases. 52

The Administrative Procedure Act (APA) requires a court to affirm an agency rule unless it is arbitrary and capricious. ${ }^{53}$ A court determines whether an agency rule satisfies that standard by evaluating the "concise general" statement of basis and purpose that must accompany the rule. ${ }^{54}$ Over the past twenty years, the appellate courts have applied the arbitrary and capricious test to agency rulemaking in a way that has replaced the statutory adjectives "concise" and "general" with the judicial adjectives "encyclopedic" and "detailed." 55

To avoid reversal and remand of a rule, an agency must consider explicitly the consistency of its rule with each of the inany inherently inconsistent goals Congress typically requires the agency to pursue. ${ }^{56}$ The agency also must consider exphicitly the issues and arguments raised in comments submitted by potentially affected members of the public. ${ }^{57}$ In the case of a rulemaking to resolve a major policy issue, those comments typically encompass tens of thousands of pages, include numerous studies commissioned by interested parties, and raise hundreds of issues. ${ }^{58}$ In order to avoid reversal and remand, the agency's discussion

50. See, e.g., Motor Vehicle Mfg. Ass'n v. State Farm Mut. Ins. Co., 463 U.S. 29, $40-44$ (1983) (reviewing court should take "hard look" at agency reasoning process); Industrial Union Dep't v. American Petroleunı Inst., 448 U.S. 607, 642-46 (1980) (OSHA unust inake threshold finding that toxic substance poses significant risk before it can regnlate substance).

51. Mashaw \& Harfst, supra note 3, at 263-68, 309-12.

52. Id. at $284-89$.

53. 5 U.S.C. $\$ 706(2)$ (A) (1982).

54. 5 U.S.C. $\$ 553(\mathrm{c})(1982)$.

55. See, e.g., Portland Cement Ass'n v. Ruckelshaus, 486 F.2d 375 (D.C. Cir. 1973); Automotive Parts \& Accessories Ass'n v. Boyd, 407 F.2d 330, 338 (D.C. Cir. 1968); see also Breyer, Judicial Review of Questions of Law and Policy, 38 ADMIN. L. REv. 363, 393 (1986); Wald, supra note 22.

56. Pierce \& Shapiro, Political and Judicial Review of Agency Action, 59 TEx. L. REv. 1175, 1186-88 (1981).

57. Id. at $1190-92$.

58. See Breyer, supra note 55, at 393; see also Costle, Brave New Chemical: The Future Regulatory History of Phlogiston, 33 ADMIN. L. REv. 195, 199 (1981). 
must demonstrate that it has "given full consideration" to each issue 59 and that it has balanced "objectively" each decisional factor. ${ }^{60}$

Professors Mashaw and Harfst's study of rulemaking by the National Highway Traffic Safety Administration (NHTSA) illustrates both the extreme scope of the obligations imposed on agency rulemaking and the effects of those obligations. ${ }^{61}$ In 1966, Congress enacted a statute that required NHTSA to promulgate rules that enhance automobile passenger safety. ${ }^{62}$ In 1971, NHTSA promulgated its most important rule by far under the statute, a rule requiring installation of passive restraints on all new motor vehicles. In 1972, the Sixth Circuit reversed and remanded that rule in Chrysler Corp. v. Department of Transportation. ${ }^{63}$ The court based its reversal on its conclusion that the rule did not meet the statutory requirement that it specify "objective performance criteria" because NHTSA's criteria for test dummies were imcomplete. ${ }^{64}$

Reviewing courts often say that an agency is required to address only "significant" or "important" issues in its statement of basis and purpose accompanying a rule. ${ }^{65}$ Chrysler illustrates, however, that any issue can be considered so significant that failure to address it "adequately" and "objectively" will yield judicial reversal and remand of a rule. The "duminy criteria" issue on which the Chrysler court predicated its reversal was considered trivial to the NHTSA proceeding-until the court issued its decision. ${ }^{66}$ Considered in the typical context of tens of thousands of comments and studies in which well-financed parties hostile to the agency's proposed policy raise hundreds of issues, the Chrysler opinion, read together with analogous opimions of other circuits, ${ }^{67}$ sends agencies a clear message. In order to survive judicial review, an agency's "concise general" statement of basis and purpose must deal comprehensively and in detail with each issue raised in comments, no matter how trivial that issue appears to the agency.

59. Scenic Hudson Preservation Conference v. Federal Power Comm'n, 354 F.2d 608, 612 (2d Cir. 1965), cert. denied, 394 U.S. 941 (1966).

60. Mobil Oil Co. v. Department of Energy, 610 F.2d 796, 801 (Temp. Emer. Ct. App. 1979), cert. denied, 446 U.S. 937 (1980).

61. Mashaw \& Harfst, supra note 3.

62. 15 U.S.C. $\S \S 1381-1431$ (1982).

63. 472 F.2d 659 (6th Cir. 1972).

64. Mashaw \& Harfst, supra note 3, at 282-83.

65. See Breyer, supra note 55, at 393.

66. Mashaw \& Harfst, supra note 3, at 283.

67. See, e.g., PACCAR, Inc. v. NHISA, 573 F.2d 632 (9th Cir. 1978), cert. denied, 439 U.S. 862 (1979); National Tire Dealers \& Retreaders Ass'n v. Brinegar, 491 F.2d 31 (D.C. Cir. 1974); H\&H Tire Co. v. Department of Transp., 471 F.2d 350 (7th Cir. 1972); Scenic Hudson Preservation Conference v. Federal Power Comm'n, 354 F.2d 608 (2d Cir. 1965). 
NHTSA understood and acted upon that message. The agency required seven years from the date of the remand in Chrysler to devise a new passive restraint policy that would survive judicial review. ${ }^{68}$ Moreover, NHTSA has abandoned almost completely its efforts to establish pohicy through rulemaking; it opts instead to use the ad hoc approach of recalling vehicles for "defects," because courts are more tolerant of agency attempts to make policy in the context of specific cases. ${ }^{69}$ Other agencies have had similar experiences, with the same result-systematic policymaking through rulemaking is being replaced either by policy paralysis or by ad hoc policymaking through adjudication. ${ }^{70}$

Courts also have diminished agency interest in systematic pohcymaking by imposing requirements that agencies "find" unfindable facts and support those findings with unattainable evidence. The D.C. Circuit's opimion in International Ladies Garment Workers' Union v. Dono$v_{a n}{ }^{71}$ is one of many illustrations. The Department of Labor (DOL) promulgated a rule that permitted employees subject to the minimum wage law to perform some functions at home. ${ }^{72}$ The International Ladies Garment Workers' Union (ILGWU) claimed in comments that DOL would not be able to enforce the minimum wage law in the homework context. ${ }^{73}$ DOL responded by referring to two studies that reached a contrary conclusion and by expressing its own opimion, as the agency charged with responsibility to enforce the statute, that it could enforce the minimum wage law in the homework context. ${ }^{74}$ The court reversed the rule on the basis that DOL's finding of enforceability was not supported by substantial evidence. ${ }^{75}$ Yet, it is difficult to conceive of any more persuasive evidence the agency could amass with respect to a purely predictive judgment like the enforceability of a new policy.

The members of the $I L G W U$ panel, like many appellate judges, seem not to realize that the bulk of agency policymaking consists of risk management under conditions of uncertainty. Very few government policies can be supported by reference to clear, objective factual predicates, because many of the critical facts are unknown and unknowable at the time an agency must make a policy decision. Moreover, as Judge Breyer has demonstrated, there is no such thing as not nuaking a policy decision,

68. Mashaw \& Harfst, supra note 3, at 295.

69. Id. at 299-302.

70. Id, at 276-302; T. MCGARITY \& S. SHAPIRO, supra note 3; S. MELNICK, supra note 3.

71. 722 F.2d 795 (D.C. Cir. 1983).

72. Id. at 799.

73. Id. at 819-20.

74. Id. at $818-19,825$.

75. Id. at 825 . 
or even deferring a policy decision. ${ }^{76}$ When an agency declines to make a decision in favor of one policy, or a court reverses an agency decision to adopt a particular policy, the agency or the court necessarily is adopting an alternative policy. Thus, most policy decisions inust be based on liiglily inperfect data.

The D.C. Circuit lias interpreted a 1987 Supreme Court decision in a inanner that deals an additional powerful blow to agency rulemaking. In its mucl1-cited 1984 opinion in Chevron U.S.A. Inc. v. Natural Resources Defense Council, Inc., ${ }^{77}$ the Supreme Court lield that a reviewing court inust defer to an agency's interpretation of an ambiguous provision of a statute that the agency is required to implement. In Union of Concerned Scientists $v$. Nuclear Regulatory Commission, ${ }^{78}$ a majority of a panel of the D.C. Circuit interpreted the Supreine Court's 1987 decision in Immigration \& Naturalization Service v. Cardoza-Fonseca ${ }^{79}$ as limiting the scope of the Chevron doctrine to agency adjudicatory proceedings.

Cardoza-Fonseca involved interpretation of the statutory tern "well founded fear of persecution." In applying the tern to Cardoza-Fonseca, INS interpreted it to require an alien to prove that slee was "more likely than not" to be persecuted if sle were returned to lier country of origin. ${ }^{80}$ Six Justices voted to reverse the agency's decision to require CardozaFonseca to return to Nicaragua based on their conclusion that the agency's interpretation of its statute was inconsistent witls "the plain language" of the statute. ${ }^{81}$ The opinion for a five-Justice majority then proceeded in dicta to discuss the apphicability of the Chevron test. The majority stated that the deference to be accorded an agency's interpretation of its statute under Chevron is limited to cases in whicls the agency gives "concrete ineaning" to a statutory tern "tlirougli a process of caseby-case adjudication." 82

76. Breyer, Vermont Yankee and the Court's Role in the Nuclear Energy Controversy, 91 HARV. L. REV. 1804 (1978).

77. 467 U.S. 837 (1984).

78. 824 F.2d 108, 113 (D.C. Cir. 1987). For additional evidence of appellate court confusion concerning the scope and meaning of Chevron, see NLRB v. FLRA, 834 F.2d 191 (D.C. Cir. 1987).

79. 107 s. Ct. 1207 (1987).

80. Id. at 1210 .

81. Id. at $1213 \mathrm{n} .12,1223,1224$.

82. Id. at 1221. The Court addressed the question of the scope and interpretation of Chevron again in NLRB v. United Food \& Commercial Workers Union, 108 S. Ct. 413 (1987). The opinion for the entire Court affirms an agency interpretation of a statutory provision, citing both Chevron and Cardoza-Fonseca. In a brief concurring opinion, four Justices "write separately only to note that [the Court's] decision illustrates the continuing and unchanged vitality of the test for judicial review of agency determinations of law set forth in Chevron." Id. at 426 (Rehnquist, C.J. \& White, O'Connor \& Scalia, JJ., concurring). The concurring opinion continues by characterizing the D.C. Circuit opinion in Union of Concerned Scientists as "mistaken." Id. 
It seems unlikely that the majority in Cardoza-Fonseca intended to himit Chevron deference to agency statutory interpretations adopted in the context of adjudication. To the contrary, given the context in which the statement was inade, the majority's reference to Chevron probably was intended to rebuke the agency for unnecessarily adopting a broad, abstract (and erroneous) interpretation of a statutory provision in the context of adjudicating a specific dispute. The passage discussing Chevron was totally superfluous dicta, since the inajority held the agency's interpretation inconsistent with the plain meaning of the statutory language. Moreover, it seems bizarre to say that Cardoza-Fonseca limits Chevron to cases in which agencies apply statutory language to specific facts, since Chevron was not such a case and Cardoza-Fonseca was. Nevertheless, the D.C. Circuit cited Cardoza-Fonseca for this proposition in Union of Concerned Scientists. ${ }^{83}$

If Cardoza-Fonseca actually stands for the proposition that an agency's interpretation of an ambiguous provision in its statute is entitled to deference when the agency apphes the provision to specific facts but not when the agency interprets the same provision in a rulenaking, the courts have added a powerful new deterrent to agency pohicymaking through rulemaking. Appellate courts already had created significant impediments to agency rulernaking by subjecting the agency factfinding and reasoning process to much more rigorous review in the context of rulemaking than in the context of ad hoc adjudication. If the agency is now entitled to deference in statutory interpretation only when it makes policy through adjudication and not when it makes policy through rulemaking, as the D.C. Circuit's interpretation of the Cardoza-Fonseca dicta suggests, it is hard to imagine why any agency administrator would choose rulemaking over adjudication as a vehicle for making policy. When the lottery effect of potential judicial review of agency policy decisions by the activist and politically polarized D.C. Circuit is combined with the extraordinarily high cost and strategic disadvantages of rulemaking created by decisions like Chrysler, ILGWU and Union of Concerned Scientists, rulemaking as a vehicle for making pohicy decisions may soon be relegated to a chapter in a legal history book.

Food \& Commercial Workers is likely to increase the existing confusion and disagreent in the lower courts concerning the scope and meaning of Chevron. Judges who favor the Chevron approach will interpret the concurring opinion as explicit Supreme Court disapproval of Union of Concerned Scientists, since there is nothing in the opinion of the entire Court inconsistent with the explicit stateinent in the concurring opinion. Judges who want to narrow the scope of Chevron will interpret Food \& Commercial Workers as an indication that only four Justices interpret Chevron broadly, since the only clear statement to that effect is in the concurring opinion. The Court obviously must revisit this issue in the near future.

83. Union of Concerned Scientists v. NRC, 824 F.2d 108, 113 (D.C. Cir. 1987). 


\section{Solutions to the Problem}

There is a rich and growing hiterature that supports the proposition that agencies enjoy significant comparative advantages over other institutions of government as sources of policy decisions. Jerry Mashaw concludes that "adininistrators should make political decisions" principally on grounds of constitutional legitimacy and pohitical accountability. ${ }^{84}$ Conferring policymaking discretion on agencies allows presidents and administrations to respond to voter preferences. ${ }^{85}$ This, in turn, permits policyınaking to take place in accordance with majoritarian principles, avoiding the high transaction cost of enacting specific legislation in Congress, which confers "enornous advantage" on the proponents of the status quo. ${ }^{86}$ This constitutional and political advantage is particularly obvious when the comparison is between agencies and courts. ${ }^{87}$ As the Supreme Court recognized in 1984, "federal judges-who have no constituency - have a duty to respect legitiniate policy choices made by those who do." $" 88$

Judge Breyer reaches the same conclusion as Mashaw through analysis of a different set of factors. ${ }^{89}$ He urges courts to defer to agency policy decisions for four reasons attributable to other characteristics of judicial and administrative bodies. No judge can understand the comphcated issues raised by an agency poticy decision based on the only source of data available to her on review-the record of the proceeding. ${ }^{90} \mathrm{Em}$ pirical data on judicial review of agency policymaking demonstrates that the effect of review is not beneficial; rather, the effect is random at best. ${ }^{91}$ Courts have little understanding of the difficulty of the process of agency data gathering and policyinaking. ${ }^{92}$ As a result, courts inipose unrealistic demands on agencies and thereby create policy paralysis. ${ }^{93}$ Tom McGarity emphasizes the last two points in his careful study of agency

84. Mashaw, Prodelegation: Why Administrators Should Make Political Decisions, I J.L. EcoN. \& ORG. $82,93-99$ (1985).

85. Id. at $95-96$.

86. Id. at 98. For an excellent discussion of the difficulty of enacting or amending a statute, see generally G. Calabresi, A Common LAw for the Age of Statutes (1982). See also Pierce, Institutional Aspects of Tort Reform, 73 CALIF. L. REV. 917 (1985).

87. See Pierce, The Role of Constitutional and Political Theory in Administrative Law, 64 TEx. L. Rev. 469, 504-13 (1985); see also Strauss \& Sunstein, The Role of the President and OMB in Informal Rulemaking, 38 ADMIN. L. REv. 181 (1986). See generally Koinesar, Taking Institutions Seriously: Introduction to a Strategy for Constitutional Analysis, 51 U. CHI. L. REV. 366 (1984).

88. Chevron U.S.A. Inc. v. Natural Resources Defense Council, Inc., 467 U.S. 837, 866 (1984).

89. Breyer, supra note 55 , at 382-94.

90. Id. at $389-90$.

91. Id. at 391.

92. Id. at $388-89$.

93. Id. at 391-94. 
policymaking. ${ }^{94}$ He describes a process in which agency decisionmakers inevitably are "awasli in a sea of uncertainties." 95

Peter Strauss arrives at the same destination as Mashaw, Breyer and McGarity througli yet a third route. He focuses on the inanagerial implications of appellate-court review of agency decisions. ${ }^{96}$ He concludes that judges should defer to agencies with respect to inany issues, specifically includimg agency interpretations of indeterminate statutory language, for three related reasons. ${ }^{97}$ First, agencies frequently have the obligation to create and impleinent a colierent, integrated program to govern a complicated and technically detailed area of regulation..$^{98}$ Courts have no sucli obligation and liave little understanding of the integrated whole the agency must attempt to create. A simgle decision by a reviewing court reversing one element of an agency's regulatory sclieme can force the agency to modify its entire integrated approacli. Second, circuit courts are likely to adopt inconsistent interpretations of indeterminate statutory language, thereby rendering it impossible for an agency to impleinent any colrerent national policy. ${ }^{99}$ Third, the Supreine Court has very limited practical ability to eliminate intercircuit conflicts. ${ }^{100}$ It can visit any particular corner of the legal environment only about once every five years. ${ }^{101}$ As a result, the Court can fulfill its obligation to obtain national uniformity in the administration of national statutes only by instructing circuit courts to defer to agency interpretations of indeterminate congressional instructions in agency organic acts.

The D.C. Circuit's imcreasing political polarity and inability to resolve intracircuit conflicts through en banc proceedings ${ }^{102}$ suggests that Strauss understated the inagnitude of the managerial problem presented by permitting courts to second-guess agency interpretations of indeterminate statutory language. Even within the single circuit that dominates judicial review of agency action, different panels give a simgle agency inconsistent instructions on lrow to do its job. ${ }^{103}$ Strauss's allusion to re-

94. McGarity, Regulatory Analysis and Regulatory Reform, 65 TEX. L. REv. 1243 (1987).

95. Id. at 1290.

96. Strauss, One Hundred Fifty Cases Per Year: Some Implications of the Supreme Court's Limited Resources for Judicial Review of Agency Action, 87 CoLUM. L. REv. 1093 (1987).

97. Id. at $1118-29$.

98. Id. at 1126-29.

99. Id. at $1120-23$.

100. Id. at $1106-07$.

101. Id. at 1103.

102. See supra text accompanying notes $16-44$.

103. For instance, two panels of the D.C. Circuit have reached totally inconsistent conclusions with respect to the Federal Energy Regulatory Commission's power and duty to modify contracts applicable to statutorily deregulated natural gas. Compare Office of Consumers' Counsel v. FERC, 826 F.2d 1136, 1139 n.2 (D.C. Cir. 1987) with Associated Gas Distribs. v. FERC, 824 F.2d 981, 
viewing courts as "the bull in the legal china shop" seems apt. ${ }^{104}$

There is a single solution to the functionally related problems of judicial deterrence of rulemaking and political polarity on the D.C. Circuit-a solution that will honor the role of agencies as superior policymaking institutions. Stated at the greatest level of generality, this solution calls for greater judicial conservatism on the part of courts im reviewing agency policy decisions. Judicial conservatism can be defined in two ways-deference to majoritarian institutions of government and adherence to judicial precedents. Although not always the case, in the context of judicial review of agency policy decisions, these definitions converge: a number of principles have been developed that call for judicial deference to agencies based on the value of agency function, and strong precedents, both in the Supreme Court and in the D.C. Circuit, support these principles. ${ }^{105}$ Judges need only apply these principles and

1027 n.30 (D.C. Cir. 1987). Other examples of conflicts between republican and democratic D.C. panel decisions abound. Compare AT\&T v. FCC, 836 F.2d 1386, 1391 (D.C. Cir. 1988) (reversing FCC contingent refund order) with New Eng. Tel. \& Tel. Co. v. FCC, 826 F.2d 1101, 1109 (D.C. Cir. 1987) (affirming FCC contingent refund order); Jersey Cent. Power \& Light Co. v. FERC, 810 F.2d 1168, 1170 (D.C. Cir. 1987) (reversing agency's disallowance of hundreds of millions of dollars in costs) with Office of Consuners' Counsel v. FERC, 783 F.2d 206, 223, 226 (D.C. Cir. 1986) (affirming agency decision and inandating that agency disallow hundreds of millions of dollars in costs); enforced per curiam, 826 F.2d 1136 (D.C. Cir. 1987), motion to enforce mandate denied, 842 F.2d 1308 (D.C. Cir. 1988); Jersey Cent, 810 F.2d at 1187-88 (refusing to acknowledge that FERC had adopted and applied "used and useful" test) with Mid-Tex Elec. Coop. v. FERC, 773 F.2d 327, 357 (D.C. Cir. 1985) (reversing agency decision to create narrow exception to "used and useful" test).

104. Strauss, supra note 96 , at 1129.

105. See, e.g., United States v. Riverside Bayview Homes, Inc., 474 U.S. 121, 131-35 (1985) (reversing appellate decision that the Army Corps of Engineers' authority under the Clean Water Act inust be narrowly construed to avoill an improper taking under the fifth amendment); Chemical Mfrs. Ass'n v. Natural Resources Defense Council, Inc., 470 U.S. 116, 125 (1985) (holding the EPA's understanding of the Clean Water Act sufficiently rational to preclude judicial second-guessing in light of considerable deference that must be shown to agencies charged with a statute's administration); Chevron U.S.A. Inc. v. Natural Resources Defense Council, Inc., 467 U.S. 837, 842-45 (1984) (absent explicit congressional direction, judicial review of an administering agency's statutory construction is linited to a determination whether such construction is "permissible"); Baltimore Gas \& Elec. Co. v. Natural Resources Defense Council, Inc., 462 U.S. 87, $97-98$ (1983) (Court's role in reviewing a decision of the NRC under the National Environmental Policy Act is limited to ensuring that such decision was reached after adequate consideration and was neither arbitrary nor capricious); FCC v. WNCN Listeners Guild, 450 U.S. 582, 596 (1981) (reversing appellate decision for failing to show due deference to an FCC policy statement in light of Congress's explicit delegation); Federal Power Comm'n v. Florida Power \& Light Co., 404 U.S. 453, 462-63 (1972) (Courts should only reluctantly reverse Federal Power Commission determinations of its own jurisdiction under the Federal Power Act if such conclusions are supported by weight of substantially supported expert testimony); Center for Auto Safety v. Peck, 751 F.2d 1336, 1342-43 (D.C. Cir. 1985) (in establishing a standard of review for a decision by the NHTSA, court must renember that decisions that require weighing of costs and benefits of alteruative pohicies are peculiarly within expertise of an agency); National Cable Television Ass'n v. Copyright Royalty Tribunal, 724 F.2d 176, 181 (D.C. Cir. 1983) (where Congress has given agency broad discretion within which to operate, court's re- 
consistently follow those precedents to reduce the problem of judicial paralysis of government pohicymaking. ${ }^{106}$

\section{A. Agency Policy Decisions on Remand.}

The D.C. Circuit is the source of a legal doctrine that has the potential to reduce the deterrent effect of the exceedingly demanding standards courts apply in reviewing agency policy decisions made through rulemaking. Traditionally, agencies and courts have drawn a direct analogy between appellate court reversal of an agency action and appellate court reversal of a trial court action. In each case, the legal status reverts back to the status quo ante unless and until the agency or trial court conducts a new proceeding on reinand. The analogy works reasonably well im the context of classic agency adjudications. Consider, for imstance, a judicial decision reversing a Social Security Administration (SSA) order because the SSA based its decision to deny benefits to an individual on madequate findings or reasoning. The agency has the discretion on remand to attempt to correct the error on which reversal was predicated by conducting a supplemental liearing to adduce additional evidence and by changing the basis for its original action. As a result, the proceeding reaches a relatively prompt conclusion.

The analogy breaks down, however, in the context of judicial reversal of an agency policy decision made through rulemaking. A judicial determination that an agency erred in the process of adopting a new policy does not necessarily mean that the status quo ante-the agency's old pohicy-is superior to the agency's new pohcy. Frequently, the basis for reversal of the new policy is remote from the central purpose and basis of the new policy. Yet, judicial review of the agency rulemaking process is so demanding that tlie process of policymaking on remand from a court decision reversing an agency rule usually requires many years.

view must be relaxed accordingly); Ethyl Corp. v. EPA, 541 F.2d 1, 34-36 (D.C. Cir.), cert. denied, 426 U.S. 941 (1976) (characterizing standard of review for cases involving agency decisions as "highly deferential"); Industrial Union Dep't v. Hodgson, 499 F.2d 467, 474-75 (D.C. Cir. 1974) (amorphous nature of policy choices justifies more deferential standard of review).

106. Unfortunately, appellate courts are not alone in their inconsistent approach to review of agency policy decisions. The Supreme Court occasionally sends signals that reviewing courts should engage in rigorous review of agency policy decisions. See, e.g., Motor Vehicle Mfrs. Ass'n v. State Farm Mut. Auto. Ins. Co., 463 U.S. 29, $41-44$ (1983). Judge Breyer criticizes State Farm in detail. Breyer, supra note 55, at 384-94. The D.C. Circuit relies primarily on State Farm to support the continued legitimacy of its "hard look" approach to agency policy decisions. See Wald, supra note 22. In my view, the Supreine Court decided State Farm correctly and accorded the agency's policy decision appropriate deference. The unfortunate effect of State Farm in encouraging appellate courts to assume an activist posture in reviewing agency policy decisions is attributable to a few passages of dicta in which the Court referred to "liard look" review with apparent approval. See R. PIERCE, S. SHAPIRO \& P. VerkUIL, supra note $45, \S 7.7$, at $394-400$. 
Mashaw and Harfst's account of the NHTSA's attempt to establish a policy concerning installation of passive restraints to enhance motor vehicle passenger safety, discussed above, illustrates the problem. ${ }^{107}$ The reviewing court in Chrysler obviously did not reach a conclusion that on the merits the nation was better off with the status quo-no required passive restraints-than with the agency's pohicy. Its basis for reversal was peripheral to that critical issue. Yet, that was the effect of the court action for many years. It took NHTSA seven years from the 1972 judicial reversal of its passive restraint rule to reissue the rule im a form ultimately affirmed by a court under the exacting standards estabhished by the Sixth Circuit in Chrysler. 108

In 1987, the D.C. Circuit took the first step toward developing a pragmatic approach to the issue of agency discretion to make policy on an interim basis after a court has reversed and remanded a major rule. In 1983, the Federal Energy Regulatory Commission (FERC) promulgated a rule that permitted electric utilities to include up to fifty percent of their investment in construction work im progress (CWIP) in their rate base if they could show that this rate treatment was necessary to alleviate financial problems encountered in constructing a new plant. In Mid-Tex Electric Cooperative v. Federal Energy Regulatory Commission ${ }^{109}$ (Mid$T e x I$ ) the court reversed and remanded the CWIP rule. The court leld that FERC had not adequately considered allegations that the rule miglit have anticompetitive effects in solne circumstances.

On remand, FERC took two actions. It issued a new notice of proposed rulemaking in which it solicited comments on the alleged anticompetitive effects of its rule and on ways in which it could avoid those effects in a revised permanent rule. Simultaneously, it issued an interim rule that repromulgated, with a few modifications, the rule that liad been reversed and remanded. The modifications consisted of assurances that the agency would attempt to provide relief to any customer that suffered anticompetitive effects as a result of application of the rule in an individual case.

The parties who obtamed judicial reversal of tlie original rule challenged the repromulgated and slightly modified interim rule on two grounds. They argued that it was substantively invalid because it was inconsistent witl the court's mandate reversing the original rule. They also argued that the intermi rule was procedurally imvalid because it was issued without notice and comment. In Mid-Tex Electric Cooperative v.

107. See supra notes $61-70$ and accompanying text.

108. See Mashaw \& Harfst, supra note 3, at 281-95 (describing Chrysler as a "managerial and political disaster" that continues to "haunt" the NHTSA's regulatory activity).

109. 773 F.2d 327, 362 (D.C. Cir. 1985). 
Federal Energy Regulatory Commission ${ }^{110}$ (Mid-Tex II) the court rejected both challenges and affirmed the interim rule.

On the substantive issue, the court noted that its prior opinion did not address the issue of FERC's authority to reproinulgate the reinanded rule on an interim basis. ${ }^{111}$ Since the prior court opinion affirmed the rationale stated as the basis for the rule, and since the agency took steps "reasonably calculated to protect custoiners froin the anticoinpetitive effects" of the rule on an interim basis, the court held the reproinulgated and shightly inodified interim rule consistent with the letter and spirit of its prior decision reversing the permanent version of the rule. ${ }^{112}$

On the procedural issue, the court held that the agency had estabhished "good cause" to promulgate the interim rule without notice and comment for three reasons. First, the rule was an interim ineasure adopted as a step in the continuing process of establishing a permanent policy. ${ }^{113}$ Second, even though the original rule was reversed, its fundainental approach was approved "in substantial ineasure."114 Third, the court affirmed FERC's finding that continuing its pre-rulenaking pohicy during the lengthy period required to formulate a permanent poticy on reinand would be "contrary to the public interest."115

The D.C. Circuit's opinion in Mid-Tex II represents a promising first step toward reducing the inulti-year policy paralysis that has resulted from judicial reversal and reinand of an agency rule. Under Mid$T e x I I$, an agency can reproinulgate proinptly a rule that was reversed and remanded if (1) the inajor eleinents of the rule were affirmed; (2) the reproinulgated rule is adopted ouly as an interim measure in an ongoing process to establish a permanent rule; and (3) the interim rule includes features that represent a good faith effort to ameliorate on an interim basis the probleins created by the original rule that caused the court to reverse that rule.

Mid-Tex II suggests that reviewing courts are becoming inore sensitive to the pohicy paralysis that frequently results froin court decisions reversing agency rules on the basis that the agency failed to consider adequately one of the hundreds of issues raised in a rulernaking proceeding. The Mid-Tex approach will reduce the scope of that problein in an important context-when the basis for judicial reversal leaves intact the rationale that hies at the core of the agency's policy and when the agency

110. 822 F.2d 1123 (D.C. Cir. 1987).

111. Id. at 1130 .

112. Id. at $1130-31$.

113. Id. at 1132 .

114. Id. at 1133 .

115. Id. at 1133-34. 
is enthusiastic to implement its new pohicy. In other important contexts, however, Mid-Tex has no effect on the problem. ${ }^{116}$ The long-term solution to the problem of pohicy paralysis attributable to frequent judicial reversal of agency rules lies in more realistic judicial attitudes toward agency policymaking in areas of scientific coinplexity and uncertainty.

\section{B. Duty to Consider Alternative Policies.}

Few judges understand the process of agency policymaking suffciently to enable thein to empathize witl the agencies whose decisions they must review. Judges search for "findings" of fact, compreliensive analysis of data and thorough consideration of inultiple alternatives. The nature of the tasks assigned agencies and the resources made available to perform those tasks do not permit agencies to meet such exacting standards. Judge Breyer helps to put the agency's pliglit im perspective with his graphic description of agency attempts to comply with the judicial command to consider alternatives and to consider criticisms raised in comments:

The reason agencies do not explore all arguments or consider all alternatives is one of practical limits of time and resources. Yet, to have to explain and to prove all this to a reviewing court risks imposing much of the very burden that not considering alternatives aims to escape. Of course, the reviewing courts may respond that only important alternatives and arguments must be considered. But, what counts as "iinportant"? District courts often find that parties, having barely inentioned a legal point at the trial level, suddenly make it the heart of their case on appeal, einphasizing its (sudden but) suprene importance. Appellate courts typically consider such arguments as long as they have been at least mentioned in the district court. But district courts, unlike agencies dealing with policy change, do not face, say, 10,000 comments challenging different aspects of complex policies. And, when appellate courts "answer" an argument they write a few words or paragraphs, perhaps citing a case or two. A satisfactory answer in the agency context may inean factfinding, einpirical research, detailed investigation. Accordingly, one result of strict judicial review of agency policy decisions is a strong conservative pressure in favor of the status quo. ${ }^{117}$

The precedent that addresses Breyer's well-supported concerns most directly and effectively is the D.C. Circuit's opimion in Center for Auto Safety v. Peck. ${ }^{118}$ The court was called upon to review NHTSA's decision to reduce the minimum performance standard for bumpers from $\mathbf{5 . 0}$

116. Consider, for instance, the situation when an agency has a legal duty to establish a policy through rulemaking, but it is not very enthusiastic about doing so. See, e.g., Public Citizen Health Research Group v. Brock, 823 F.2d 626 (D.C. Cir. 1987).

117. Breyer, supra note 55 , at 393.

118. 751 F.2d 1336 (D.C. Cir. 1985). 
to 2.5 miles per hour. The Center for Auto Safety challenged that decision on a wide variety of grounds, including inadequate consideration of alternatives and inadequate data to support the decision. The court rejected each basis for challenge. It began by einphasizing that judicial deference is particularly appropriate "when the agency is called upon to weigh the costs and benefits of alternative pohicies, since '[s] uch cost-benefit analyses epitomize the types of decisions that are most appropriately entrusted to the expertise of an agency." "119 It declined to reverse the agency for relying on one set of data while refusing to rely on conflicting data, noting the Supreme Court's admorrition that "it is within the agency's discretion to pass upon the generalizability of . . . field studies." "120 It also declined to reverse the agency's decision to rely on its judgment to resolve a major gap in available data rather than to conduct expensive and time-consuming studies in an atteinpt to determine the magnitude of "unknowable risks of injury."121 Finally, the court affirmed the agency's decision to evaluate only two of the infinite number of theoretically available alternatives to the pohicy decision it inade. ${ }^{122}$ It found the agency's consideration of alternatives adequate notwithstanding a patent error in part of the agency's analysis and reasoning: "Considering the record as a whole, we cannot say that this single error on an alternative point-blatant though it may be-renders the entire rulemaking arbitrary or capricious." 123

Center for Auto Safety places an agency's duty to consider alternatives and to consider contrary arguinents in realistic perspective. An agency cannot possibly consider more than a very few alternatives. Its analysis and reasoning always will contain flaws. The data available to it to analyze alternatives invariably will leave inajor gaps and uncertainties. Reviewing courts inust tolerate a level of perfornance well short of comprehensive analysis of alternatives.

\section{Agency Policy Decisions as "Findings of Fact."}

Toin McGarity's careful study of agency policymaking highhights other critical features of the process that reviewing courts inust understand. Because agencies regularly address "questions plagued by inultiple uncertainties and a scarcity of infornation, ... [a] bright lawyer and

119. Id. at 1342 (quoting Office of Communication of the United Church of Christ v. FCC, 707 F.2d 1413, 1440 (D.C. Cir. 1983)).

120. Id. at 1346 (quoting Motor Vehicle Mfrs. Ass'n v. State Farm Mut. Auto. Ins. Co., 463 U.S. 29, 53 (1983)).

121. Id. at 1349.

122. Id. at 1365 .

123. Id. at 1366 . 
two or three technical aides can make almost any regulatory analysis document appear to be irrational." 124 Precedents abound that support the need for judicial deference to agency policymaking im conditions of uncertainty. 125

In Federal Power Commission v. Florida Power \& Light Co., 126 the Supreme Court was presented witl a challenge to an agency "finding" that electricity flowed in a particular way. The company argued that the agency had not supported the finding witl substantial evidence because it had accepted the theory of one expert and rejected inconsistent theories presented by other experts without evidence tliat established which theory was "correct." The court of appeals reversed the agency on the basis that "expert opinion about the nature of reality . . . is not fact."127 The Supreme Court reversed the court of appeals and affirmed the agency:

[W] hold that well-reasoned expert testimony ... may in and of itself be "substantial evidence" when first-hand evidence on the question ... is unavailable. This proposition has been so long accepted ... that we do not consider it fairly in dispute. ${ }^{128}$

Yet, appellate courts reject this "long accepted" principle at least as often as they accept it.

The D.C. Circuit's decision in Electricity Consumers Resource Council v. Federal Energy Regulatory Commission ${ }^{129}$ (Elcon) illustrates the tendency of appellate courts to iguore what the Supreme Court characterizes as a "long accepted" principle. FERC adopted marginal cost principles as its basis for calculating wholesale electric rates. It relied on expert testiunony to support its finding that marginal cost pricing would enhance economic efficiency. ${ }^{130}$ The court reversed the agency based in part on a lack of substantial evidence to support this finding: "[M]ere reliance on an econounic theory cannot substitute for substantial record evidence."131 Another panel of the D.C. Circuit has analogized this part

124. McGarity, supra note 94 , at 1329 .

125. See, e.g., United States v. Riverside Bayview Homes, Inc., 474 U.S. 121 (1985); Chemical Mfrs. Ass'n v. Natural Resources Defense Council, Inc., 470 U.S. 116 (1985); Chevron U.S.A. Inc. v. Natural Resources Defense Council, Inc., 467 U.S. 837 (1984); Baltimore Gas \& Elec. Co. v. Natural Resources Defense Council, Inc., 462 U.S. 87 (1983); FCC v. WNCN Listeners Guild, 450 U.S. 582 (1981); Federal Power Comm'n v. Florida Power \& Light Co., 404 U.S. 453 (1972); Center for Auto Safety v. Peck, 751 F.2d 1336 (D.C. Cir. 1985); National Cable Television Ass'n, Inc. v. Copyright Royalty Tribunal, 724 F.2d 176 (D.C. Cir. 1983); Sierra Club v. Costle, 657 F.2d 298 (D.C. Cir. 1981); Ethyl Corp. v. EPA, 541 F.2d 1 (D.C. Cir.), cert. denied, 426 U.S. 941 (1976); Industrial Union Dep't v. Hodgson, 499 F.2d 467 (D.C. Cir. 1974).

126. 404 U.S. 453 (1972).

127. Id. at 464 .

128. Id. at 464-66.

129. 747 F.2d 1511 (D.C. Cir. 1984).

130. Id. at 1513 .

131. Id. at 1514. 
of the Elcon holding to a requirement that an agency "conduct experiments in order to rely on the prediction that an unsupported stone will fall."132 Economists characterize marginal cost pricing as "the central policy prescription of microeconomics."133

The Supreme Court's decision in Baltimore Gas \& Electric Co. v. Natural Resources Defense Council, Inc. ${ }^{134}$ provides another good illustration of powerful precedent instructimg courts to defer to agency policy decisions made im conditions of uncertainty. The Nuclear Regulatory Commission (NRC) issued a rule that hicensing boards should assume that permanent storage of nuclear waste will have no adverse effect on the environment for purposes of deciding whether to grant a license to any particular nuclear power plant. ${ }^{135}$ The D.C. Circuit reversed the NRC on the basis that its finding of no adverse environmental effect was arbitrary and capricious. ${ }^{136}$ The Supreme Court unanimously reversed the D.C. Circuit and affirmed the NRC. The Court noted that the NRC did not predicate its poticy on a "finding" of no adverse environmental effect. ${ }^{137}$ The NRC explicitly acknowledged the existence of uncertainty concerning the environmental effects of permanent storage of nuclear waste. ${ }^{138}$ Its directive to assume the absence of environmental effects of permanent nuclear waste storage im plant licensing decisions was a pohicy decision that the risks were too uncertain to use their existence as a basis for denying a hicense to any particular power plant. ${ }^{139}$ In affirming the agency, the Court reemphasized the "long accepted" principle that courts should defer to agency policy decisions made im conditions of uncertainty:

Resolution of these fundamental policy questions hes ... with Congress and the agencies to which Congress lias delegated autlority ....

....

... [A] reviewing court must remember that the Commission is making predictions, within its special expertise, at the frontiers of science. When examining this kind of scientific determination, as opposed to simple findings of fact, a court must generally be at its most deferential. ${ }^{140}$

By following Louisiana Power \& Light and Baltimore Gas \& Electric, and applying the "long accepted" primciple that courts must defer to reason-

132. Associated Gas Distribs. v. FERC, 824 F.2d 981, 1008 (D.C. Cir. 1987).

133. 1 A. KaHN, THE ECONOMICS OF REgulation 65 (1970).

134. 462 U.S. 87 (1983).

135. Id. at $89-90$.

136. See id. at 95 .

137. Id. at 98-99.

138. Id.

139. Id. at 101-03.

140. Id. at 97, 103. 
able agency policy decisions, appellate courts can reduce materially their inadvertent role in creating policy paralysis. The D.C. Circuit also can use adherence to this important principle as a way of reducing the political polarity that now infects that court's decisionmaking.

\section{Agency Policy Decisions in the Form of Interpretations of Indeterminate Congressional Instruction.}

Appellate courts also must recognize that a high proportion of agency interpretations of statutory language actually are policy decisions due deference by the unelected judiciary. The Supreme Court recognized this inportant principle in its oft-cited opinion im Chevron U.S.A. Inc. v. Natural Resources Defense Council, Inc. ${ }^{141}$

The issue in Chevron was the proper interpretation of the term "source," as that term is used in the 1977 Amendments to the Clean Air Act. That Act requires any company that proposes to create a major new source of air pollutants to go through an elaborate "new source review" process. ${ }^{142}$ The Environmental Protection Agency (EPA) originally interpreted "source" in a way that subjected any significant addition to or modification of a plant, such as addition of a boiler, to the new source review process, as long as the addition or modification produced emissions of pollutants above a relatively low threshold. In 1981, the EPA changed its interpretation of "source" to refer to an entire plant. Under this much broader definition, a company was required to go through the new source review process only if the net effect of all additions or changes proposed at a plant would be an increase in emissions above the specified threshold. Thus, a coinpany conld avoid the new source review process by sinultaneously increasing emissions through an addition to a plant and reducing emissions by a corresponding amount through other modifications to the same plant. This change in statutory interpretation was part of the EPA's movement to the "bubble concept," which is intended to give company management greater control over specific decisions affecting air quahty as long as the total impact of a plant on air quality is not affected negatively by those decisions.

The Natural Resources Defense Council (NRDC) appealed the EPA's new interpretation of "source." The D.C. Circuit recognized that the language and legislative history of the statute did not mdicate how "source" was to be interpreted. ${ }^{143}$ The court itself had adopted different

141. 467 U.S. 837 (1984).

142. Clean Air Act Amendments of 1977, Pub. L. No. 95-95, 91 Stat. 685.

143. Natural Resources Defense Council, Inc. v. Gorsuch, 685 F.2d 718, $723-24$ (D.C. Cir. 1982), rev'd, 467 U.S. 837 (1984). 
interpretations of the term in different contexts in its prior opinions. ${ }^{144}$ The D.C. Circuit reversed the EPA's interpretation in the present context, however, because the EPA did not subinit any studies to rebut the NRDC's contention that the EPA's new interpretation of source would produce less iniprovement in air quality than its old interpretation. ${ }^{145}$ The court held that an agency cannot change its policy without documenting the effect of such a change. The court seemed untroubled by the fact that the EPA's old interpretation, and thus the policy underlying that interpretation, also was not supported by studies demonstrating the effect of various statutory interpretations. Indeed, there was no evidence available concerning the air quality inipact of the two competing interpretations, and experts disagree concerning the likely effect of each.

The Supreme Court unanimously reversed the D.C. Circuit and affirmed the EPA's new interpretation of "source" based on the following reasoming. The language of the statute and its legislative history indicated that Congress never addressed the issue of whether "source" was to be interpreted to mean each part of a plant or an entire plant. 146 The EPA's new interpretation furthered one of the two principal goals of the 1977 amendinent-permitting economic growth. ${ }^{147}$ There was no evidence available concerning the inipact of the new imterpretation on Congress's other major goal-iniproving air quality. ${ }^{148}$ Hence, the EPA's choice of interpretations reflected a pure policy decision im an area in which Congress delegated the EPA power to inake such policy decisions.

The Court used strong language in rebuking the D.C. Circuit for the expansive role it assuined in reviewing the EPA's policy decision. In the Court's words, the D.C. Circuit "Inisconceived the nature of its role."149 "[F]ederal judges-who have no constituency-have a duty to respect policy choices made by those who do."150 The Court noted that judges are neither experts in the field nor members of "either pohtical branch of government." 151 By contrast, agencies are politically accountable experts to whom Congress has delegated a policymaking role. ${ }^{152}$ The Court concluded with this unequivocal statement: "The responsibilities for assessing the wisdom of such policy choices and resolving the struggle

144. Alabama Power Co. v. Costle, 636 F.2d 323, 373 (D.C. Cir. 1979).

145. 685 F.2d at $720,727-281$

146. Chevron U.S.A. Inc. v. Natural Resources Defense Council, Inc., 467 U.S. 837, 864 (1984).

147. Id. at 866 .

148. Id.

149. Id. at 845 .

150. Id. at 866 .

151. Id. at 865 .

152. Id. at $865-66$. 
between competing views of the public interest are not judicial ones."153

Some commentators liave misunderstood the Court's message in Chevron. They cliaracterize it as a case in which the Court mexplicably departed from the fundamental principle that judges should decide issues of law. ${ }^{154}$ This characterization is based on a serious misunderstanding of the legislative process. ${ }^{155}$

Any time Congress enacts a statute that creates a new regulatory regime, it creates the need for some governmental institution to resolve liundreds of policy issues. Congress resolves some of those issues itself at the timc it enacts the statute. When a court reviews an agency's interpretation of statutory language, its responsibility is to determine what the language means. If it finds evidence that Congress addressed the policy issue that corresponds to the interpretive issue before it, the reviewing court must confine the agency's choice of policies within the boundaries established by legislative resolution of policy issues. The court does so by reversing any agency interpretation inconsistent witl congressional intent. Thus, for instance, a reviewing court slould reverse the EPA's interpretation of "source" as a matter of law if it finds a statutory definition of "source" inconsistent with the EPA's interpretation or an imdication in the language or legislative history of the statute that Congress considered and rejected the "bubble concept" that the EPA's interpretation of "source" would implement. In the absence of sucli evidence, the court fulfills its responsibility to declare what the law is by holding that the term "source" is sufficiently ambiguous to support the EPA's interpretation.

The court's task does not end at this point. It then must review the agency's interpretation of the ambiguous statutory terin to see whether it is arbitrary and capricious. In performing this responsibility, lowever, the court is reviewing an agency's policy decision. It sliould adhere to the "long accepted" primciple that reviewing courts should defer to agency policy decisions as long as they are "reasonable." Since the effect of the "bubble concept" on pursuit of the congressional goal of enhanced air quality is uncertam, the court should affirm the EPA's decision to adopt the "bubble concept" by holding "reasonable" the agency's interpretation of the ambiguous statutory tern "source."

Consistent adlierence to the principle announced in Chevron is a particularly important component of the solution to the twin problems of

153. Id. at 866 .

154. Sunstein, Judicial Review of Administrative Action in a Conservative Era, 39 ADMiN. L. REv. 353, 366-71 (1987); Breyer, supra note 55, at 372-82.

155. See Pierce, Chevron and Its Aftermath: Judicial Review of Agency Interpretations of Statutory Provisions, 41 VAND. L. REV. 301 (1988); Pierce, supra note 87, at 473-81, 504. 
judicial deterrence of rulemaking and political polarity on the D.C. Circuit. If judges view their responsibilities to include determining congressional intent with respect to issues Congress did not address, they will find it impossible to perform their roles in a politically neutral manner. Anyone who attempts to determine the meaning of indeterminate statutory language is bound to be greatly influinced by her personal pohitical perspective. If judges consistently defer to agency interpretations of indeterminate congressional instructions, and confine their role to enforcing those policy decisions Congress actually has inade, they are far less likely to succumb to the temptation to make disguised policy decisions based on their own pohtical perspective.

The D.C. Circuit's holding in Union of Concerned Scientists ${ }^{156}$ represents the worst possible approach to the issue of judicial review of agency interpretations of ambiguous statutory language. By holding that courts should defer to an agency if, but only if, its interpretation is adopted in the adjudicatory process, the D.C. Circuit simultaneously exacerbates both of the major problems that are the focus of this paper. If the judges of the D.C. Circuit feel obliged to determine congressional intent with respect to issues on whicl Congress has expressed no intent, they will be forced to resolve major public policy issues every time they review a major agency ruleinaking. This will inevitably increase the already considerable political polarity on the D.C. Circuit. At the same time, courts will have given agency administrators the message tliat the only relatively safe inetliod of administrative policyinaking is througl inaking pohicy decisions disguised as ad hoc resolutions of specific disputes.

\section{CONCLUSION}

The appellate courts have made the process of policymaking by rulemaking extraordinarily expensive and time consuming by imposing unrealistic requirenents on agencies. The politically polarized and judicially activist D.C. Circuit, which dominates judicial review of agency rulemaking, has added a high degree of risk to the process of pohicymaking through rulemaking. If these two problems persist, agencies will have to follow the lead of the NHTSA - they will cease attempting to make policy decisions in any systematic inanner.

It seems apparent that the Supreine Court must play a significant role in solving these fnnctionally related problems. It should reemphasize in a few inore cases the point it has so often made in the pastreviewing courts must adhere to the "long accepted" principle that

156. 824 F.2d 108 (D.C. Cir. 1987); see supra text accompanying notes 75-83. 
unelected judges must defer to policy decisions made by politically accountable agencies. At bottom, however, the Supreme Court cannot solve the problem; it can only point in the right direction. Chief Judge Wald identified the only true solution in 1986:

I am afraid the only solution lies in genume self-restraint on the part of our judges .... . 157

157. Wald, supra note 1 , at 34. 